\title{
Testing times: careers market policies and practices in England and the Netherlands
}

Citation for published version (APA):

Hughes, D., Meijers, F., \& Kuijpers, M. (2015). Testing times: careers market policies and practices in England and the Netherlands. British Journal of Guidance and Counselling, 43(2), 183-201.

https://doi.org/10.1080/03069885.2014.940280

DOI:

10.1080/03069885.2014.940280

Document status and date:

Published: 01/01/2015

Document Version:

Peer reviewed version

Document license:

CC BY-SA

Please check the document version of this publication:

- A submitted manuscript is the version of the article upon submission and before peer-review. There can be important differences between the submitted version and the official published version of record. People interested in the research are advised to contact the author for the final version of the publication, or visit the DOI to the publisher's website.

- The final author version and the galley proof are versions of the publication after peer review.

- The final published version features the final layout of the paper including the volume, issue and page numbers.

Link to publication

\section{General rights}

Copyright and moral rights for the publications made accessible in the public portal are retained by the authors and/or other copyright owners and it is a condition of accessing publications that users recognise and abide by the legal requirements associated with these rights.

- Users may download and print one copy of any publication from the public portal for the purpose of private study or research.

- You may not further distribute the material or use it for any profit-making activity or commercial gain

- You may freely distribute the URL identifying the publication in the public portal.

If the publication is distributed under the terms of Article 25fa of the Dutch Copyright Act, indicated by the "Taverne" license above, please follow below link for the End User Agreement:

https://www.ou.nl/taverne-agreement

Take down policy

If you believe that this document breaches copyright please contact us at:

pure-support@ou.nl

providing details and we will investigate your claim.

Downloaded from https://research.ou.nl/ on date: 26 Apr. 2023 
This article was downloaded by: [Frans Meijers]

On: 11 August 2014, At: 06:40

Publisher: Routledge

Informa Ltd Registered in England and Wales Registered Number: 1072954 Registered

office: Mortimer House, 37-41 Mortimer Street, London W1T 3J H, UK

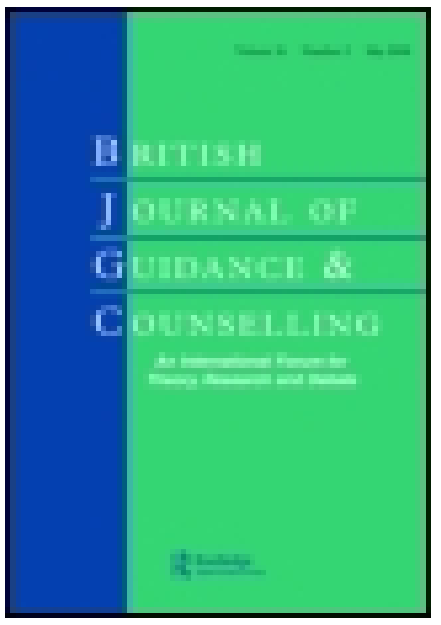

\title{
British J ournal of Guidance \& Counselling
}

Publication details, including instructions for authors and subscription information:

http:// www.tandfonline.com/ loi/ cbjg20

\section{Testing times: careers market policies and practices in England and the Netherlands}

\author{
Deirdre Hughes ${ }^{a}$, Frans Meijers ${ }^{b} \&$ Marinka Kuij pers ${ }^{b c}$ \\ a Institute for Employment Research, Warwick University, Exeter, \\ England \\ ${ }^{b}$ Department of Applied Sciences, The Hague University, The \\ Hague, The Netherlands \\ ' Department of Applied Sciences in Pedagogics of Vocational \\ Development, Welten Institute Research Centre for Learning, \\ Teaching and Technology, Heerlen, The Netherlands \\ Published online: 08 Aug 2014.
}

To cite this article: Deirdre Hughes, Frans Meijers \& Marinka Kuijpers (2014): Testing times: careers market policies and practices in England and the Netherlands, British J ournal of Guidance \& Counselling, DOI: 10.1080/03069885.2014.940280

To link to this article: http:// dx. doi.org/ 10.1080/ 03069885.2014.940280

\section{PLEASE SCROLL DOWN FOR ARTICLE}

Taylor \& Francis makes every effort to ensure the accuracy of all the information (the "Content") contained in the publications on our platform. However, Taylor \& Francis, our agents, and our licensors make no representations or warranties whatsoever as to the accuracy, completeness, or suitability for any purpose of the Content. Any opinions and views expressed in this publication are the opinions and views of the authors, and are not the views of or endorsed by Taylor \& Francis. The accuracy of the Content should not be relied upon and should be independently verified with primary sources of information. Taylor and Francis shall not be liable for any losses, actions, claims, proceedings, demands, costs, expenses, damages, and other liabilities whatsoever or howsoever caused arising directly or indirectly in connection with, in relation to or arising out of the use of the Content.

This article may be used for research, teaching, and private study purposes. Any substantial or systematic reproduction, redistribution, reselling, loan, sub-licensing, systematic supply, or distribution in any form to anyone is expressly forbidden. Terms \& 
Conditions of access and use can be found at http://www.tandfonline.com/page/termsand-conditions 


\title{
Testing times: careers market policies and practices in England and the Netherlands
}

\author{
Deirdre Hughes $^{\mathrm{a} *}$, Frans Meijers ${ }^{\mathrm{b}}$ and Marinka Kuijpers ${ }^{\mathrm{b}, \mathrm{c}}$ \\ ${ }^{a}$ Institute for Employment Research, Warwick University, Exeter, England; ${ }^{b}$ Department of \\ Applied Sciences, The Hague University, The Hague, The Netherlands; ${ }^{c}$ Department of Applied \\ Sciences in Pedagogics of Vocational Development, Welten Institute Research Centre for Learning, \\ Teaching and Technology, Heerlen, The Netherlands
}

(Received 12 March 2014; accepted 5 June 2014)

\begin{abstract}
Careers work is a very political business. Since the early 1990s, successive governments in England and the Netherlands have persistently challenged those working in the careers sector to demonstrate the educational, social and economic value and impact of their work. In this context, the marketisation of career guidance policies and practices has expanded, with a growing assumption that market-based goods and services ensure greater responsiveness to consumer choice and offer better and/or more innovative services for lower prices. In this article, we do not intend to give a comparison of trends in England and the Netherlands. We only examine the impact of market principles applied to career guidance provision in both countries. Findings indicate such provision for young people is on a steady decline. Lessons learned from these two nations indicate that a market for quality career services does not exist in schools and colleges. As a result, marketisation and privatisation of career services have led to an impoverished and fragmented supply of services. Greater attention by governments in career guidance policies for young people (and adults) is necessary to reduce the widening gap between 'the haves and have nots' in society. Failure to reduce labour market mismatch through new forms of careers dialogue is not only damaging and costly for individuals, families and employers, but for the taxpayer too.
\end{abstract}

Keywords: career guidance; marketisation; careers policy; impact assessment; evidence base

\begin{abstract}
Adam Smith in 'The Wealth of Nations' divides the public purposes of education into two parts: that which can be acquired through daily experience 'without any attention of government' and that for which 'some attention of government is necessary'. (Smith, 1937, p. 734)
\end{abstract}

\section{Introduction}

In the twentieth century various countries have developed different, and often complex, ways of funding and managing career guidance and/or counselling for young people and adults (Hohenshil, Amundson, \& Niles, 2013). Such arrangements are situated in differing legislative, economic, social, political and cultural contexts which strongly influence the design and delivery of careers and counselling policies and practices in

*Corresponding author. Email: deirdre.hughes3@btinternet.com 
schools, colleges, higher education institutions, public employment services and other community settings (CEDEFOP, 2011; HOPES, 2013; Hughes, 2012; Organisation for Economic Co-operation and Development [OECD], 2004). The starting points for each country are different (Organisation for Economic Co-operation and Development [OECD], 2004), the type and intensity of interventions that may be promoted sometimes differ (Killeen, 1996), as do the effects of market principles, including privatisation measures ${ }^{1}$ (Hughes \& Gray, 2004; Watts, Hughes, \& Wood, 2005). We set out to consider the effects of government policies in careers provision in England and the Netherlands. Being mindful that the nature and effects of service design and delivery will be different, our approach is to begin a journey of knowledge creation on the nature, scale and impact of market principles impacting on careers work.

We realise that some but not all of the changes we report in this article can be described as 'marketisation'. Actual steps in this direction in both countries have been limited. We nevertheless choose to consider the changes that took place in the provision of careers services from the perspective of marketisation, because in many respects this has been and still is the 'leading policy' with regard to the provision of careers services in England as well as the Netherlands. Very little research has been conducted into the effects of market principles applied in career guidance focusing on the quantity and quality of the services (Meijers, 2001) and cost benefits to governments (ELGPN, 2012). Further, despite Organisation for Economic Co-operation and Development (OECD, 2004), Watts and Fretwell (2004) and CEDEFOP (2009) country studies, we know of no systematic comparative studies on this topic that have examined more than two or three countries at a time. Thus, we begin by investigating examples in two countries in Western Europe.

Marketisation is 'the process in which market forces are imposed on public services, which have traditionally been planned, delivered and financed by local and central government' (Whitfield, 2006, p. 7). They do not evolve naturally nor do they emerge through self regulation, but instead 'states make markets - they create the conditions, regulations and financing and provide the legitimacy to create and sustain markets in public services' (op.cit). Marketisation and privatisation in public sector services have grown rapidly in a wide range of public administrative systems in response to neoliberal policies (Rosskam, 2006). The Thatcher and Reagan governments in the 1980s abandoned the policy of state intervention to maintain full employment. They deregulated financial and labour markets, privatised public assets, reduced tax rates, promoted free trade and small government. While the state-maintained sector has been contracting out services, with diminishing state funds (alongside a consequent growing need to raise additional support from business, parents and the local community), the governments in England and the Netherlands have given positive encouragement to alternative private institutions and contracting-out of services. In both nations, governments have forged ahead with making markets in most public services, with the role of government transformed into making, supporting and sustaining markets.

\section{Marketisation of career guidance services: England 1991-2013}

In 1991, the Conservative government announced the introduction of legislation to remove responsibility to deliver careers services from local education authorities (LEAs) and to make the Secretary for State for Employment responsible for providing the service (Bayliss, 2000). This was a radical shift from previous arrangements and reflected the Conservative government's ideology and policies. At the time, legislation (Parliament, 1993) set out the access of careers services to schools, so that career guidance could be 
provided to complement careers education. New partnership arrangements included responsibility for supporting the extended duty on schools to provide planned programmes of careers education from Year 7 onwards (Department for Education and Skills [DfES], 2004). The government aimed to reduce the influence of local authorities (LEAs) on services and increase the influence of local employers. There was money for careers libraries in schools and an extra $£ 87$ million of funds invested by government in the set up of the new careers services following 'contractorisation'. The 1993 Act paved the way for all kinds of private-and-public sector organisations to operate career services. Most services administered under 'the new arrangements' operated by various forms of partnership between LEAs and Training and Enterprise Councils (TECs). A minority were run by private- or voluntary-sector agencies or by services from other areas. The statutory client group comprised those in full-time education at any institution outside of the higher education sector; part-time students in work-related further education; and young people under 21 years old who had left education up to two years previously. Work with adults was encouraged, and if they so wished, services were allowed to charge clients outside of the statutory group (Killeen \& Kidd, 1996, p. 161). An era of outputrelated funding began ( $15 \%$ of funds was based on completed action plans) with a strong emphasis on contracts, accountability and the 'new market' demanded innovation and flexibility. The first articulation of the concept of Individual Learning Accounts (ILAs), voucher-based provision of guidance for adults, was in the report of the Commission for Social Justice (1994).

\section{The rise and fall of Connexions Services and 'Nextstep'}

When the Labour Government was in office (1997-2010), they initially tried to distance themselves from the marketisation and privatisation concept. However, new initiatives such as Education Action Zones (designed to address schooling in deprived areas through match-funding from government and businesses) were labelled as 'test-beds' for privatisation (Chitty, 1997). In 1998, a new strategy for information, advice and guidance for adults (IAG) was announced by government, with $£ 54 \mathrm{~m}$ funding made available over three years (Jackson, Watts, Hughes, Bosley, \& El-Sawad, 2001). Funding was allocated to 67 Careers Services working in local partnerships, including community and voluntary groups. It is also important to note that funding was not allocated for guidance per se. In a few cases, there were no plans to introduce a charging policy; however, some services reported steady demand for charged services, including psychometric testing. The major challenge highlighted was to offer a guidance service to those in the target group of returners, unemployed and low skilled who cannot afford to pay (Jackson, Watts, Hughes, Bosley, \& El-Sawad, 2001, p. 13).

Alongside this, a new universal and targeted Youth Support Service brought an end to unified all-age Careers Service. The Connexions Service was also rolled out across England between April 2001 and April 2003 on a phased basis in 47 Connexions Partnership areas co-terminous with Learning \& Skills Council (LSC) areas. The rebranded and refocused service (at a cost to the taxpayer of at least $£ 450$ million per annum) established a new brand, a cadre of around 8000 Personal Advisers, a series of one-stop shops and sub-regional partnerships. This was intended to help all young people between the ages of 13-19, and to support 20- to 24-year-olds with learning difficulties and/or disabilities, particularly those most disadvantaged and disaffected. Many of the Connexions providers were also leading on IAG Partnerships. Watts (2001) highlighted two fundamental design flaws: firstly, the development of the service built around 
targeted provision with the universal service bolted-on, and secondly, the aim of merging youth, careers and educational welfare services was only part-implemented. Hoggarth and Smith (2004) raised concerns about the fluidity of young people's transitions and the leakage in young people being 'lost to the system'. Despite this, in early 2005, the Minister of State for Children praised the Connexions service for achieving a $14 \%$ reduction nationwide in the number of young people not in education, employment or training (National Connexions Partnership Ltd., 2005). Legislative, funding, refocusing and market changes (Hughes, 2005) had further opened up 'the market' resulting in career services offering fee-charged services to employers, including outplacement services or broader human resource development services, fee-charged services to individuals, commonly costed on a marginal-cost basis (subsidised by other sources of funding), and publically funded services free to individuals, mainly unemployed adults. There were major operational considerations in looking ahead at service design and delivery, including the issue of contestability and the continued drive for greater choice and openness. The term 'contestability' is used to describe the extent to which there is pressure upon a provider to improve services and/or reduce costs, either through the presence of potential competitors, or in the case of a single provider, where there is a threat of a potential competitor entering the market.

\section{An all-age National Careers Service}

In 2010, the newly formed Conservative and Liberal Democrat Coalition Government announced 'the days of big government are over: that centralised control and top-down have proved a failure' (HMG, 2010). The values of freedom, fairness and responsibility, including greater autonomy for schools, and shifts towards more localised control of budgets and services were emphasised, linked to achieving greater economic prosperity and social mobility. The Minister for Skills formally announced a new all-age National Careers Service (NCS) to build on the best of Connexions and Next Step and to strengthen the partnership model. The service was formally launched in April 2012, through a joint initiative of the Department for Business, Innovation \& Skills (BIS) and the Department of Education (DfE). The overall budget is provided by a number of government departments. In $2012 / 2013$ this totalled $£ 106$ million, comprising $£ 84.4 \mathrm{~m}$ from BIS; $£ 14 \mathrm{~m}$ from the Ministry of Justice; $£ 4.7 \mathrm{~m}$ from DfE; and $£ 1.5 \mathrm{~m}$ from the Department for Work \& Pensions (National Careers Council [NCC], 2013). Previously, the budget alone for Connexions Services was estimated at around £200million (House of Commons Education Select Committee, 2013). However, a significant tightening of fiscal policies was articulated by government, with schools, colleges and local authorities' deemed solely autonomous institutions 'best placed to decide on their own careers provision'.

The NCS rapidly built up capacity and expertise, creating 12 regional infrastructures and the NCS contracted online national telephone and web-based services, but in reality it is supporting mainly (though not exclusively) adults. A cadre of over 2500 qualified career development professionals are employed by 12 Prime Contractors. Co-location in Job Centre Plus, Further Education Colleges and community walk-in arrangements are in place, ranging from libraries, council service outlets, community centres to mosques and high street shops. In this context, face-to-face careers services are available from the NCS but to adults only. This is juxtaposed with, for example, less than $1 \%$ of young people $(0.8 \%)$ using the telephone service and $0.6 \%$ using webchat facilities (National Careers Council [NCC], 2013: 13). Yet, the potential for increased usage of ICT and digital-based guidance remains significant. Until recently, the NCS had been subjected to wider 
government fiscal policies preventing the marketing of their goods and services. Therefore, the NCS's ability to stimulate demand from young people and adults has been stymied. The marketplace is not working to good effect.

In September 2013, the new Minister for Skills \& Enterprise formally launched his 'Inspiration Vision Statement'(HMG, 2013) amidst growing concerns that career services for young people in England are on the decline. He stated: 'The Government is committed to improving the quality of careers information, advice and guidance, and we believe that the new statutory duty on schools and the equivalent requirements on colleges are an important step towards this'. The focus on inspiration for young people and 'the best motivation and advice tend to come from people in jobs themselves' is reflected in strong policy leverage for more employers to 'step up and offer more career opportunities to young people' (UKCES, 2013). Competitions for innovation in labour market intelligence and enterprise initiatives are on the increase, stimulated financially by government. The market continues to be stimulated by government to encourage more competition, enterprise and innovation. In March 2014, the procurement of area-based contracts for the NCS resulted in further changes in providers within and across the regional infrastructures. Overall, there are growing calls for the NCS to provide a brokerage role between employers and schools with research underway to examine what this might possibly look like (Skills Taskforce, 2014). Local Enterprise Partnerships (LEPs) comprising local authorities, city initiatives, employer bodies, employers, schools, colleges and universities will help determine future provision in their respective areas. This presents both new challenges and opportunities for a NCS. In some cities, such as London, there have been calls for greater investment in local careers services. Yet, the NCS offers significant potential to ensure provision is not geographically constrained and supports individuals' career management skills, in moving jobs and seeking new opportunities beyond their immediate locality throughout their lives. In January 2014, the NCS ban on marketing was lifted by the Cabinet Office, resulting in a 'Here for You' campaign, aimed at job seekers and career changers.

\section{Education}

In September 2012, schools were faced with the biggest change to the provision of careers guidance for almost 40 years. After four decades of having available a publicly funded service, they were given a statutory duty to secure access for their pupils to 'independent and impartial careers guidance', with no ring-fence funding to commission such services. Andrews (2013) highlighted concerns that careers work must now compete with other school spending in the absence of dedicated funding, alongside the removal of statutory duty to provide careers education (and work-related learning) within the curriculum. The new education landscape requires young people to make early subject choice decisions (some from 13 years old upwards) and the recent raising of the participation age from 16- to 18-years-old by 2015 signals a new and challenging era for this current generation of school pupils (and their parents and teachers).

Schools provision has changed with new school types emerging in the marketplace such as free schools, academies, university technology colleges (UTCs) and studio schools (Ofsted, 2013). These institutions have different arrangements and responsibilities, with some not directly obliged to adhere to the new statutory duty. Findings from various reports highlight some examples of good/interesting careers practice and innovation in schools, such as an increase in clustering activities. However, major shortfalls remain prevalent (British Chamber of Commerce, 2014; Confederation of 
British Industry [CBI], 2012; House of commons, 2013; National Careers Council [NCC], 2013; Ofsted, 2013). The Ofsted Inspectorate is critical of the current state of careers guidance for young people. The opening paragraph states that 'the new statutory duty for schools to provide careers guidance is not working well enough.' It recommended an urgent revision of the statutory guidance for schools, recognising a critical success factor in meeting their new statutory duties is the institutions' appetite and ability to secure access to independent and impartial careers guidance in crowded 'marketplace'. The government will also share best practice, improve the quality of destination data and task schools to publish details of the careers guidance support they provide. The NCS is to extend its work with young people by facilitating school employer links, promoting to schools and career development professionals the availability of labour market intelligence and information (LMI) and making available resources to support schools, young people and parents. Finally, Ofsted will give greater priority to careers guidance in further school inspections. Yet, schools and colleges need to build skills and capacity in their workforce, learn best practice and access reliable labour market information to help deliver career management skills, including career adaptability competences and resilience in young people as labour markets continue to change. As schools and college funding tightens this becomes more difficult.

In English schools, most careers work takes place with 15- to 16-year-olds in Year 11, with $88 \%$ of pupils in this year group receiving some form of careers support in 2012/2013 (Coffait, 2013). Coffait conducted a survey of 355 individuals from 230 schools across all regions in England, examining the overall pattern of careers work in English schools over $2011 / 2012$ and in 2012/2013. Findings suggest a mixed picture; more than $7 \%$ reported a drop in careers provision. Despite the relatively small decline in provision, the results by school type highlight that secondary state school staff are considerably more pessimistic than their private (independent) school counterparts. Whereas around a quarter of state schools responding to the survey identified a drop in provision, this was only true for 1:10 private schools (p. 23). Figures suggest declines in work experience: 14\% in career libraries, $12 \%$ in individual career counselling, $9 \%$ and $7 \%$ in career learning as part of the 'citizenship' curriculum. Careers fairs and the use of interest inventories and psychometric testing also decreased by 6-7\%. Interestingly, embedding teaching about careers as a cross-curricular theme has grown by $5 \%$. The revised statutory guidance for schools and colleges (Department for Education [DfE], 2014) highlights external sources of careers guidance and inspiration could include employer visits, mentoring, website, telephone and helpline access. Taken together, these external sources could include information on the range of education and training options, including apprenticeships. The role of careers advisers receives only a brief mention in the document (p. 13). A culture change in careers provision is underway. Roberts (2013, p. 251) asserts:

there has been an attempt in England to cull a service perceived as redundant since secondary schools, like universities and many further education colleges, have become capable (even if less knowledgeable and skilled) of offering a service on which a distinct career guidance profession has increasingly concentrated.

Local Authorities responsible for meeting the needs of NEET young people have also reported an overall decline in the quality and quantity of careers support available for young people (Langley, Hooley, \& Bertuchi, 2014). Alongside this, there is a growing body of evidence on the long-term penalties for individuals when career ambitions are uncertain or unrealistic (Yates, Harris, Sabates, \& Staff, 2011). It has been shown that 
young people who were uncertain or unrealistic about their career ambitions at 16 went on to be three times more likely to spend significant periods of times being NEET, compared to their peers. It has also been shown that young people from disadvantaged backgrounds are nearly twice as likely to suffer from such confusion as their more prosperous counterparts (Ashby \& Schoon, 2010; Sabates, Harris, \& Staff, 2011). The Social Mobility and Child Poverty Commission (2013) highlighted the need to halt the trend of the last decade, where the top part of society prospers and the bottom part stagnates. To avert this, Milburn (2013) indicates policy-makers need to come to terms with a new truth that emerges. Although entrenched poverty has to be a priority - and requires a specific policy agenda - transient poverty, growing insecurity and stalling mobility are far more widespread than politicians, employers and educators have so far recognised.

\section{Labour markets}

Evidence clearly shows the British youth labour market is not working effectively (Gardiner \& Wilson, 2012; Mann, Massey, Glover, Kashefpadkel, \& Dawkins, 2013; National Careers Council [NCC], 2013). A sharp rise in skills shortages threatens to hold back the pace of recovery in parts of the British economy (UKCES, 2014). In spite of being, on average, more highly qualified, and bringing more years of education than any previous generation, young people in English schools face unemployment rates which are now three times greater than adults over 24. In the early 1990s, that ratio was just twice as high - levels which are seen in continental European countries such as the Netherlands and Germany. Employer bodies such as the Confederation of British Industry (CBI, 2012) and the British Chamber of Commerce (BCC, 2014) have recently called for careers education and employer visits to schools to begin early, so as to inform later subject choices. The former is pushing hard for a new approach to schooling.

But adults too are facing major challenges. With changing expectations of how long people will work, and as the workforce ages, there are challenges in supporting the midcareer workers who will need to maintain a set of work-related competences and manage effective work transitions for much longer than has been customary in the past. There is a distinct lack of tailored careers support for people aged 50+, particularly those in lowpaid employment. Difficult choices lie ahead for the NCS and its future priorities, including brokerage activities between schools and employers in a highly competitive arena. The National Careers Council, comprising senior leaders from business, education and the careers sector, presented its first report to government in July 2013. As a result, steps are being taken by the Skills Funding Agency (SFA) - responsible for the NCS - to be assisted by the creation of an Employer-led Advisory Body comprising senior representatives from employers, education and the careers development profession to help guide its work and ensure it delivers 'value for money' and meets the needs of young people, adults and employers. Challenging times lie ahead for the all-age NCS as it navigates its way partnering with a myriad of market players from private, public, voluntary and community organisations.

\section{Marketisation of career guidance services: the Netherlands 1991-2013}

In 1991, the Dutch Department of Education concluded that 'career education and guidance is (...) of utmost importance' (Ministry of Education and Science, 1991). At that time, existing career guidance services were reproached for being fixated on the interests of the individual and being insufficiently aware of the needs of employers. 
The view was that the interests of the latter should be integrated more visibly into career guidance services and, according to the Ministry, this was best done by allowing the market to play a more important role in the provision of such services. The decision to marketise/commercialise guidance services was not a purely Dutch decision as a similar line of development could be observed in a number of other European countries (Bartlett, Rees, \& Watts, 2000; Rees \& Bartlett, 1999; Rees, Bartlett, \& Watts, 1999).

\section{Situation before marketisation}

Until the late sixties, guidance services were provided by completely subsidised independent offices. Children from higher social classes tended to benefit most from such career guidance services (Pere, 1986). However with the increased meritocratisation of society, every pupil was soon entitled to career guidance and the corresponding 'equal opportunity' for upward mobility. By the late sixties, every school for secondary education was legally required to appoint at least one career counsellor or so-called career teacher. The independent offices were also heavily subsidised to extend their services to all pupils, but the age of those consulting the independent offices basically remained the same (Pere, 1986, p. 140). In the early eighties, it became apparent that huge quantitative and qualitative discrepancies existed between the educational system and the labour market. In addition to the independent offices for careers guidance and career teachers, two new players therefore entered the field of career guidance. First, so-called 'contact centres' for education and work were founded in 1985 to improve the relations between schools and the regional labour market. This was done mainly by arranging for expanded and better placement of pupils within labour organisations. Second, in 1980, regional offices for the apprenticeship system started providing pupils with information on the dual learning system, thereby offering minimal guidance for those pupils following such a dual learning route. Adults could obtain free career guidance via yet another player: the employment office, but only if they were unemployed and the employment office decided that such career advice was clearly necessary. Adults could also consult an independent office for careers guidance but at their own cost and, as Wolf (1994) has shown, very few adults were willing to do so.

Career guidance was initially rather directive (Pere, 1986) but due to the growing democratisation of society, emphasis on group discussions and the emergence of counselling in the 1970s, career guidance became more concerned with the process of increasing self-awareness (Meijers, 1995). Career guidance services were also aimed at the 'widening of one's horizon,' which Taborsky and De Grauw (1974, p. 116) understood to include all those activities which:

help to open the eyes of the individual for the world surrounding him, for his social situation, for the place he takes therein, for the environment that determines the scope of his views, for the degree to which he has been determined by his gender role, for his school situation, that sometimes only represents a very small world.

In everyday reality, however, the emphasis in guidance services was on the psychometric testing of clients (Blommers \& Lucassen, 1992; Meijers, 1995). 


\section{The Advice Offices for Education and Occupation}

In 1993, the independent offices for career guidance, the contact centres for education and work and the regional offices for the apprenticeship system were forced to merge into 16 regional guidance centres: the Advice Offices for Education and Occupation (Dutch term: AOB). The purpose of the merger was: (i) to reduce the existing fragmentation in the field of career services, (ii) to realise a better connection with the regionally operating community colleges and employment boards (regionalisation) and (iii) to enlarge the influence of the schools and employment boards on the guidance services provided (so-called 'market steering'). The explicit purpose was to abolish all direct grants for the newly formed Advice Offices; they instead had to earn every penny on the 'free market'. After a fierce struggle between, on the one hand the Department of Education and the Central Employment Board and on the other hand the Advice Offices, a compromise was reached.

In 1996, 100\% of the money which the Department of Education (i.e. the Directorate for Vocational Education and the Directorate for General Secondary Education) and 60\% of the money which the Employment Service channelled to the Advice Offices in 1995 was still ear-marked for the Advice Offices. This meant that the schools and regional employment boards did not receive a penny to spend on the market themselves, but were still obliged to purchase all of their services from the Advice Offices. In 1997, only 30\% of the money was still ear-marked for the Advice Offices and a quasi-market for career guidance services existed. In 2000, the marketisation of the guidance services was complete. Between 1996 and 1999, the Advice Offices did not receive the ear-marked money directly but only if contracts with schools and regional employment boards for at least $85 \%$ of the total ear-marked sum were realised. Realisation of $<85 \%$ resulted in serious cutbacks.

By January 1993, there were 16 Advice Offices. Then by January 1997 there were 12 and by January 2000 there were 7 left. After that the numbers dwindled further; by January 2013 there was only one Advice Office remaining. This office, called Compaz, is part of the Calder Holding that delivers services including diagnostics and assessment and work and career counselling both in the UK and the Netherlands (www.calderholding.nl). All the takeovers were arranged without an exchange of funds because Advice Offices would otherwise have gone bankrupt. The reduction from 16 to 1 Advice Office goes hand in hand with a reduction in personnel. In 1993 about 1300 people (an estimated $550 \mathrm{fte}$.) worked at the various Advice Offices; in 2000 about 600 (estimated $250 \mathrm{fte}$.) and in 2012 that was reduced to 125 professionals (67 fte.).

Table 1 shows that in $1993,54 \%$ of the revenue was generated by education, $23 \%$ by municipalities (including employment service), $19 \%$ by the business sector and $4 \%$ by individual customers. In $2010,72 \%$ of the revenue was generated by municipalities (e.g. services directed towards the reintegration of the long-term unemployed including marginalised groups such as ex-junkies, etc.), $16 \%$ by education and $12 \%$ by the business sector - the market for individual customers disappeared completely. In 2011, as a result of cutbacks in education and municipalities caused by the economic crisis, earnings dropped significantly, but still the biggest customer is the local government $(66 \%$ of the total revenue).

Revenue is generated for the most part through testing. In education, $17 \mathrm{fte}$ of personnel time is spent on the carrying out of diagnostic tests with regard to choice of study and talent development. In services provided to municipalities, diagnostic tests are done with the unemployed with the aim of labour market reintegration, which accounts 
Table 1. Revenue generated by different groups of customers for all Advice Offices in 1993 and for Compaz in 2010 and 2011 (in absolute figures and \%).

\begin{tabular}{|c|c|c|c|c|c|}
\hline & \multirow{2}{*}{$\begin{array}{c}\text { All Advice } \\
\text { Offices } 1993 \\
\%\end{array}$} & \multicolumn{2}{|c|}{2010} & \multicolumn{2}{|c|}{2011} \\
\hline & & Absolute $(€)$ & $\%$ & Absolute $(€)$ & $\%$ \\
\hline Education & 54 & $1,697,900$ & 16 & $1,226,000$ & 16 \\
\hline Municipalities & 23 & $7,526,000$ & 72 & $5,106,500$ & 66 \\
\hline Business sector & 19 & $1,204,700$ & 12 & $1,411,200$ & 18 \\
\hline Individuals & 4 & - & - & - & - \\
\hline Total & 100 & $10,428,600$ & 100 & $7,743,700$ & 100 \\
\hline
\end{tabular}

Source: Figures for all Advice Offices from the Joint Bureau of the Advices Offices (Gemeenschappelijk Bureau voor Opleiding en Beroep [GBOB], 1994); figures for Compaz from the statements of account.

for 20 fte. of professionals' time. In companies the tests are done (i) for selection purposes and for career development and (ii) for work and health and $30 \mathrm{fte}$. is dedicated to this. The conclusion is clear: in education the emphasis of the services provided is on choice of study (not choice of profession/vocation). In municipalities (i.e. local councils) the emphasis is on quick labour-market reintegration, and in the business sector, the focus is on selection and the prevention of burnout. There is indeed very little attention paid on career development and if there is, this only happens in the business sector.

The directors of Compaz decided in 2000 that they would not actively invest in education, in particular because they believed that schools would remain clients. This assumption was correct and schools continued - out of habit - to buy the tests, with as a consequence that Compaz employees had no reason to innovate or to become innovative. As of 2012 there are two kinds of services provided by Compaz within education: (i) online service provision, especially existing psychometric testing and diagnostic testing (yearly about 30,000 students are tested) and (ii) psychological guidance, provided by psychologists to gifted students or to students who are serious athletes. According to its director, as of 2012, Compaz does not have the skills to work and think along with schools about more narrative approaches to careers orientation and guidance and to train teachers in new forms of career guidance. Since 1993 de-professionalizing has been taking place:

This didn't happen to us. The choice was made to focus on other opportunities. The budget for career guidance that was first spent on career guidance, ended up in the lump sum of schools because it was not earmarked. Because a portion of these resources could also be spent on accommodations etc. this market became too uncertain.

In the period between 2000-2006 Compaz decided to focus on labour-market reintegration, which had been hitherto dominated by municipalities. As an effect of a government policy, in which labour market participation was key, municipal budgets grew in the area of reintegration. After 2006 the activities were determined for the most by government policies that forced individual employers to help with the integration of employees who were at risk of losing their jobs. The government expected that the number of employees who would leave the labour market because of burnout or for other stress-related reasons would be reduced significantly if employers (and not the government) had to cover the costs of reintegration. This would not only be good for 
government finances but also for individual employees. However, in the current market, diagnostic tests are not enough, more attention needs to be paid to actual reintegrationrelated guidance.

The director of Compaz is of the opinion that career services are going to become increasingly important because of the ageing population, the fact that people have to keep working longer, and because of questions arising about the meaningfulness of work in an ever-more individualizing culture. That said, Compaz aims to align this aim with existing diagnostic testing, preferably online which would require little personal career guidance. Schools moreover feel that career advice is the responsibility of parents and they now require that parents pay for the services provided by Compaz. In 2012, 18 of the 256 schools that made use of the services of Compaz, used a construction where parents paid a portion of the service fees.

In the early 1990s, the Ministry of Education expected that marketisation would improve the quality of career guidance services in and outside of education. Service providers of guidance services would - as a result of increased competition - offer better and/or more innovative services for lower prices. Schools would improve the services they offered because they would concentrate on the provision of basic services and be able to buy specialised services for low prices through the Advice Offices. The same would apply to municipalities and local government organisations with regard to services for (long-term) unemployed workers. In the end, individual students, those looking for work and those already working would benefit from the broad and affordable supply of services; all as a result of marketisation. But what has come of these predictions? Clearly the service of individual providers has not become more broad or innovative. Not only have the number of Advice Offices shrunk between 1993 and 2013 to one but the last Advice Office in existence provides diagnostic testing which - if one looks at what generates revenue - is inaccessible to many individuals. However, perhaps this scalingdown of the commercial supply is compensated for by the increase in diversity of what is offered by education and/or the organisations for employers and employees (i.e. trade unions); it is something we will examine below.

\section{Education}

In 2006 a large-scale research project was undertaken in order to find out under which conditions students between the ages of 12 and 24 were most able to develop the career competencies (i.e. career management skills) needed for today's labour market and to build a career identity (Kuijpers \& Meijers, 2012a; Kuijpers, Meijers, \& Bakker, 2006; Kuijpers, Meijers, \& Gundy, 2011; Meijers, Kuijpers, \& Bakker, 2006). In total 8319 students and 537 teachers from 46 schools participated in the research. It became clear that the use of techniques like having classroom conversations, career-interest tests, etc., or the presence of special experts (e.g. career teachers) contributed to the acquisition of career competencies and career identity. What was most essential however was (i) experiential learning (a problem-based curriculum) and (ii) a career dialogue at school and on the work floor (i.e. place where work placements took place). A career dialogue is a conversation that a student has with an adult whom he/she trusts (preferably a teacher, guidance counsellor and/or mentor), in which the meaning of one's life and work and the experiences that a student has had in work placement situations are made explicit. The career dialogue in school and also the conversations with experienced professionals contribute to the formation of three career competencies, namely: career reflection (i.e. capacity and motivation reflection), career forming (i.e. exploring career possibilities and 
making conscious choices) and networking, and applying these competencies in a reallife choice or learning experience. Both these types of dialogues have more of an effect on the development of career competencies than personal factors.

In only 3 of the 226 classrooms studied a strong learning environment was present. Such an environment refers to one that is problem based and dialogical and in which students have a say in what their particular learning track will look like. The research shows that the dialogue is the aspect that is missing in almost all the schools studied. In the study, teachers and students were asked how the guidance relating to competences looks concretely, for instance career reflection (i.e. exploring one's own qualities and motives) and career forming (i.e. exploring work possibilities, via for instance work placements and directing one's own school career based on the experiences with work). Almost half of the students $(46.9 \%)$ say that almost nothing is done with regard to "career reflection'. Almost a third of students feel that 'career forming' is not attended to and therefore becomes their responsibility $(31.9 \%)$. The students do not agree with the view of their teachers that a career dialogue is important for career forming. Only $9.4 \%$ indicates that he/she is helped by such a conversation. It is notable that $22.6 \%$ of the teachers and $28.8 \%$ of students do not feel that students have any choice about how their programme is offered to them.

These findings are confirmed by the results of the so-called 'JOB-Monitor 2005'. Table 2 shows how students in senior vocational education view the guidance they receive. Only $30 \%$ are (very) satisfied about the guidance of their study and career choice, $24 \%$ are (very) dissatisfied and $46 \%$ neutral. They are slightly more satisfied with guidance about their programme of studies or when it comes to personal problems, but about these subjects a majority are neutral or even negative. Students are the most satisfied about the guidance they receive about their programme of studies, but even then only $38 \%$ of them say they are (very) satisfied.

Since 2006, the quality of career guidance has not improved. Oomen (2010) concludes that guidance services in vocational education are more developed than in general education. In both vocational and general education, however, the guidance provided focuses primarily (though not exclusively) on supplying information about continuing education. Although a recent study showed the effectiveness of coaching interventions (Steeg, Elk, \& Webbink, 2012), in vocational education emphasis is put on 'compulsory reflection' in the form of personal development plans and portfolios (Mittendorff, 2010; Mittendorff, Brok, \& Beijaard, 2010). Still a vast majority of students in secondary education and in senior secondary and higher vocational education are not developing career management skills (career competencies). Most barely think about their careers at all, take no action to influence their school careers with a view to their career wishes and do not network (Meijers, Kuijpers, \& Gundy, 2013). A real career dialogue is still missing (Winters, Meijers, Lengelle, \& Baert, 2012a, 2012b; Winters et al., 2013). And last but not

Table 2. Evaluation of guidance regarding course of studies, personal problems and the choice of education and/or career (in \%).

\begin{tabular}{lccccccc}
\hline & Very poor & 2 & 3 & 4 & Very good & $N(=100 \%)$ \\
\hline Guidance about course of studies & 5 & 14 & 43 & 31 & 7 & 133.321 \\
Support with regard to personal problems & 5 & 11 & 43 & 30 & 11 & 127.775 \\
Guidance with study/career choice & 7 & 17 & 46 & 24 & 6 & 126.846 \\
\hline
\end{tabular}

Source: JOB Monitor 2005, page 89 (own representation). 
least: because schools assume that students in their final years of pre-vocational and secondary senior vocational education have already made a career decision, they are excluded from guidance services (Oomen, Van den Dungen, Pijls, \& Egelie, 2012, p. 23).

The vast majority of career counsellors working in Dutch education have little or no training (Luken, 2009; Organisation for Economic Co-operation and Development [OECD], 2002). Training as a school counsellor generally consists of a short course lasting no more than a few days. Some school counsellors have completed a two-year training course. In its yearly report about the state of education the Education Inspectorate concludes that $50-70 \%$ of all teachers insufficiently master complex skills, including the guidance of individual students. In 2012 the programme 'Career guidance in senior secondary vocational education' started up; this is a programme intended to stimulate career guidance and which is subsidised by the Ministry of Education. In the programme teams of teachers were trained to be able to have narrative career conversations. This training project appears to have a positive effect on the content of the career dialogue that teachers have with students, but also in the application and acquisition of career competencies by students (Kuijpers \& Meijers, 2012b).

\section{Labour market}

There is a wide variety of different career-guidance services in the employment sector, offered by both private and public providers. These services are highly differentiated by target group, sector and/or region. And for almost all of these services there is "no information on whether, or how, professionally trained career guidance practitioners are involved (...)' (Oomen et al., 2012, p. 35). First, there are career-advice services for trade union members - these happen on a very small scale and make use of digital career tests (see e.g. www.abvakabofnv.nl). Second, there are career-guidance services insourced by local and regional governments for their employees. These services have not been researched; no aggregated data are available on this topic either. Third, there is career guidance for job-seekers and special target groups with members who have few prospects on the labour market. The Ministry of Social Affairs and Employment (SZW) is responsible for labour-market policy (including the reintegration of unemployed or incapacitated workers) but municipalities play a role too. Organisation for Economic Co-operation and Development (OECD , 2002) cited the extensive network of Centres for Work and Income now the UWV Jobs Centres - as one of the strengths of the Dutch system. The UWV Job Centres provide job-seekers with only limited career guidance services; it often outsources this task to the private sector re-integration and career guidance firms (like Calder Holding and Compaz). The aim here was to become 'career centres' (Zoetmulder, 2010), but this evolution is uncertain since the Ministry of Social Affairs and Employment recently decided to digitise the UWV's standard services (which means that services are again reduced to testing). The extent to which career guidance is included in the services provided differs from one region to another: 'It is in any event not a main focus of attention; the emphasis is on helping individuals find work, or on "matching" job-seekers and jobs' (Oomen et al., 2012, p. 34). From the information provided above by Compaz, it is clear that the focus continues to be on the provision and the interpretation of standardised tests.

Finally, in recent years, personal-advice services were created based on collective agreements. Although more than $40 \%$ of these collective agreements provide career guidance for working people (Scholt, Dekkers, \& Ketelaar, 2010), scarcely any provision is made for career guidance in employment organisations (Organisation for Economic Cooperation and Development [OECD], 2004). Sector-based Education and Training Funds 
employ career advisors (Opleiding en Beroep, 2010), but - according to stakeholders their training and career guidance practices differ considerably. Funds focus mainly on training and invest very little in career guidance (Van den Berg, Meijers, \& Sprengers, 2006). Much of the training (48\%) is job-specific, but some of it (38\%) certainly focuses on career development (Donker van Heel et al., 2008). Only the building and construction sector has developed a more comprehensive approach in which career guidance plays a role. Fundeon, the knowledge and advice centre for education and development of personnel in the building and construction sector, started the 'Career track building \& infrastructure' for employees who wanted positions with better pay, who wanted to change their work because of health-related reasons, or who were at risk of unemployment. This track is paid for by the building sector. Clients are directed primarily to a (new) job in the sector, but the career advisors are independent. Career advisors use tests to determine the capacities of their clients and they check the motivation of their clients in a one-on-one conversation. If it becomes clear that a client has enough motivation and skill to be trained for another job, the client and adviser make an individual development plan (IDP) together. On the basis of this IDP, a training programme is started. In 2012, when many employees became unemployed as a result of the economic crisis, 1698 clients entered the programme. Of these, 418 made the transition to a new job (Brink, 2012).

\section{The careers market - where next?}

Since 2004 the OECD highlighted that a key public-policy issue was to clarify the role of markets in career-guidance provision. It noted that public policies based on the notion that career guidance is both a private and a public good could seek to work at least in part through 'the market'(Organisation for Economic Co-operation and Development [OECD], 2004, p. 120). This claim was contested immediately. Grubb (2004) set out several reasons why career guidance is hard to run through private markets, stating that it is particularly difficult to specify or clearly define supply and demand. Also, career guidance is highly variable in nature and often subsumed in other services such as education and welfare reform. Others suggested that many of the individuals who most need career guidance are least able to pay for it themselves, and least likely to be willing to do so (Watts et al., 2005). Our findings seem to confirm these concerns.

Career services in the Netherlands have certainly not improved in the last 20 years qualitatively nor quantitatively. The reality is that:

- the services offered by independent offices for career guidance (Advice Offices) and the UWV Job Centers (part of the Ministry of Social Affairs and Employment) are reduced to testing only;

- the number of Advice Offices has shrunk from 16 in 1993 to only 1 in 2012;

- schools only buy tests from Advice Offices; other more innovative services are not available;

- until now schools are incapable to create qualitatively good career services by themselves. Most career conversations with students in schools are monologues in which teachers offer information. Strong career-learning environments are almost absent. As a result most students do not develop career competencies and/or a career identity;

- the career services developed by sector-based Education and Training Funds are dominated by a trait-and-factor approach, aimed at a quick re-allocation of employees within the sector. 
Careers services in England have also not improved in the last 20 years due to constant change and political preferences. The reality is that:

- the NCS faces significant challenges ahead in terms of its offer to young people and brokerage role with schools;

- the number of NCS providers has reduced at a regional level;

- schools have yet to prove they can meet the new statutory guidance requirements;

- careers conversations with employers linking with schools are on the increase compared to a decade ago;

- career learning environments are taking new forms (both online and offline), though the overall penetration and impact in an open and unregulated market remain contested between policy-makers and those delivering at a grass-roots level.

What lessons can be learned from the contrasting, but similar, experiences in England and the Netherlands? First, the historical evolution of a careers service and profession constantly up-rooted by successive governments now requires some form of stabilisation and a more coherent careers support system(s). Finding a way to reduce fractures in the careers support system rather than create new ones is paramount. The role of employers, educationalists and careers professionals working more closely together to achieve this end goal has yet to be fully realised. Second, the available evidence demonstrates a market for quality career services does not exist in schools and colleges. Lessons from the Netherlands show marketisation of career guidance leads to an impoverished supply of services, both in the quantitative as well as in the qualitative sense. This can also reduce innovation and significantly narrow the 'careers offer' to young people (and adults). Third, those who can afford to pay for career support services will continue to do so while others unable or unwilling to pay, will, unless the state intervenes, be further disadvantaged resulting from a lack of career management skills, including career adaptability and resilience. Fourth, in England the collective intelligence of the local and NCS, on which professionals can draw, cannot be built and retained exclusively through private contractors who can be replaced at the end of a three-year contracted period - a public service provides stability and scalability of resources and efficiency savings. Fifth, inspirational talks from employers and employees (career insights) are necessary, but such talks, and other employer/employee activities, need to complement, not replace, independent and impartial careers guidance.

Strong leadership is essential in setting out a vision for careers work in schools and colleges. Strengthened 'Statutory Guidance' from government can help assert the expected basic requirement, but more is needed from the career development profession, for instance by making available to schools a directory of career providers who meet nationally recognised quality standards, harnessing technology and utilising labourmarket intelligence and information more readily. Finally, making education and careersystems work more effective will require a culture change in careers provision, whereby young people and adults are better informed and supported to make well-informed and realistic decisions about their future prospects. There is widespread agreement also that in order for individuals to succeed in education and the workplace new forms of career dialogue are necessary as well as new competences. The knowledge and skills that are needed in today's world are different from the skills that have underpinned education and employment systems in the previous two centuries. They include more resilience and self direction as well as a resonance with what choices are truly meaningful and therefore intrinsically motivating. There are choices; there are things for all parties concerned to do. 
No evidence suggests the fate of career work is sealed. Those in it and those supporting it have many choices to make, choices that take into account what supports and what deteriorates careers services and what contributes to a systematic continuity of good practices as well as qualitative improvements.

\section{Note}

1. The term 'privatisation' is capable of many different interpretations where education is concerned.

\section{Notes on contributors}

Dr Deirdre Hughes is an Associate Fellow at Warwick University, Institute for Employment Research, England.

Prof. Dr Frans Meijers is a professor at The Hague University for Applied Sciences. He is head of the research group 'Pedagogics of Vocational Development' in the Netherlands.

Prof. Dr Marinka Kuijpers is a professor at the Open University in 'Career development and learning environment in vocational education' and at The Hague University for Applied Sciences in 'Pedagogics of Vocational Development' in the Netherlands.

\section{References}

Andrews, D. (2013). The future of careers work in schools in England: Second supplementary paper. Stourbridge: Career Development Institute.

Ashby, J. S., \& Schoon, I. (2010). Career success: The role of teenage career aspirations, ambition value and gender in predicting adult social status and earnings. Journal of Vocational Behavior, 77, 350-360. doi:10.1016/j.jvb.2010.06.006

Bartlett, W., Rees, T., \& Watts, A. G. (2000). Adult guidance services and the learning society. Emerging policies in the European Union. Bristol: The Policy Press.

Bayliss, V. (2000). Joined-up guidance: Where for we go from here? Derby: Centre for Guidance Studies, University of Derby.

Blommers, A. J., \& Lucassen, W. I. (Eds). (1992). Standpunt en Horizon [Viewpoint and horizon]. Amsterdam and Lisse: Swets \& Zeitlinger.

Brink, B. (2012). Monitoring Loopbaantraject Bouw \& Infra $3^{e}$ kwartaal 2012 [Monitoring transitions structural engineering, 3rd quarter]. Harderwijk: Fundeon.

British Chamber of Commerce (BCC). (2014). Skills and employment manifesto. London: Author.

CEDEFOP. (2009). Guidance and counselling for learning, career and employment. Thessaloniki: European Centre for Vocational Training.

CEDEFOP. (2011). Lifelong guidance across Europe: Reviewing policy progress and future prospects. Thessaloniki: European Centre for Vocational Training.

Chitty, C. (1997). Privatisation and marketisation. Oxford Review of Education, 23(1), 45-68. doi: $10.1080 / 0305498970230105$

Coffait, L. (2013). A cloudy horizon: Career services in England: Careers 2020 phase two. London: The Pearson Think Tank.

Commission for Social Justice. (1994). Strategies for national renewal. London: Vintage.

Confederation of British Industry (CBI). (2012). Learning to grow: What employers need from education and skills. CBI/Pearson Education and Skills Survey 2012. London: Author.

Department for Education (DfE). (2014). Careers guidance provision for young people in schools. London: Author.

Department for Education and Skills (DfES). (2004). Extension of the statutory duty on schools to provide planned programmes of careers education in the curriculum to include years $7 \& 8$ : Guidance for middle schools. Sheffield: Author.

Donker van Heel, P., van Velden, J., Siegert, J., Groenendijk, R., de Kogel, M., \& Singer, E. (2008). Hoe werken sectorfondsen? [How do sector funds operate?] Rotterdam: ECORYS.

ELGPN. (2012). Lifelong guidance policy development: A European resource kit. Finland: University of Jyväskylä, p. 52. 
Gardiner, L., \& Wilson, T. (2012). Skills mismatch analysis: Hidden talents. London: Centre for Economic and Social Inclusion.

Gemeenschappelijk Bureau voor Opleiding en Beroep (GBOB). (1994). AOB-aktiviteiten in kaart gebracht: resultaten inventarisatie aktiviteiten AOB's in 1993 [A map of AOB activities: Results of an inventarisation in 1993]. Houten: Author.

Grubb, W. N. (2004). An occupation in harmony: The roles of markets and government in career information and guidance. International Journal for Educational and Vocational Guidance, 4(2-3), 123-139. doi:10.1007/s10775-005-1743-1

HMG. (2010). The coalition government: Our programme for action. London: Whitehall.

HMG. (2013). Inspiration vision statement. London: Department of Business, Innovation \& Skills. Retrieved from https:/www.gov.uk/government/uploads/system/uploads/attachment_data/file/ 238841/bis-13-1176-inspiration-vision-statement-R2.pdf

Hoggarth, L., \& Smith, D. (2004). Understanding the impact of Connexions on young people at risk. (DfES Research Report RR607). London: Department for Education and Skills.

Hohenshil, T. H., Amundson, N. E., \& Niles, S. G. (2013). Counselling around the world: An international handbook. Alexandria: American Counselling Association.

House of Commons. (2013). Careers guidance for young people: The impact of the new duty on schools (Education Select Committee Seventh Report of Session 2012-2013), Vols. 1 \& 2. London: The Stationery Office Ltd.

HOPES. (2013). HOPES and PES efficiency working group final report. Brussels: European Commission. Retrieved from http://ec.europa.eu/social/main.jsp?catId=105\&langId=en

House of Commons Education Select Committee. (2013). Career guidance for young people: The impact of the new duty on schools, seventh report of session 2012-2013. London: Parliament.

Hughes, D. (2005). Connexions: Developing options and opportunities. Derby: Centre for Guidance Studies, University of Derby.

Hughes, D. (2012). Improving lifelong career guidance and ICT support project: Legislation on career guidance in EU member states. Croatian Public Employment Service and Tribal Education Ltd. European Lifelong Guidance Policy Network: Progress. 2012b.

Hughes, D., \& Gray, S. (2004). A market in career provision? Learning from experiences on the East Coast of America. Derby: Centre for Guidance Studies, University of Derby.

Jackson, C., Watts, A. G., Hughes, D., Bosley, S., \& El-Sawad, A. (2001). Careers services work with adults. Derby: Centre for Guidance Studies, University of Derby.

Jongerenorganisatie Beroepsonderwijs/JOB. (2005). JOB-monitor 2005; onderzoeksresultaten ODIN 3. Amsterdam: JOB.

Killeen, J. (1996). The learning and economic outcomes of guidance. In A. G. Watts, B. Law, J. Killeen, J. Kidd, \& R. Hawthorn (Eds.), Rethinking careers education and guidance: Theory, policy and practice (p. 83). London: Routledge.

Killeen, J., \& Kidd, J. (1996). The careers service. In A. G. Watts, B. Law, J. Killeen, J. Kidd, \& R. Hawthorn (Eds.), Rethinking careers education and guidance: Theory, policy and practice (p. 161). London: Routledge.

Kuijpers, M., \& Meijers, F. (2012a). Learning for now or later? Career competencies among students in higher vocational education in the Netherlands. Studies in Higher Education, 37, 449-467. doi:10.1080/03075079.2010.523144

Kuijpers, M., \& Meijers, F. (2012b). Leren luisteren en loopbaanleren. De effecten van een professionaliseringstraject voor mbo-docenten [Learning to listen and learn career. The effects of an in-service training for vocational teachers]. Woerden: MBO Diensten.

Kuijpers, M., Meijers, F., \& Baker, J. (2006). Krachtige loopbaangerichte leeromgevingen in het (v)mbo: hoe werkt het? [Powerful career-oriented learning environments in (V) MBO: How does it work?] Driebergen: Het Platform BeroepsOnderwijs.

Kuijpers, M., Meijers, F., \& Gundy, C. (2011). The relationship between learning environment and career competencies of students in vocational education. Journal of Vocational Behavior, 78(1), 21-30. doi:10.1016/j.jvb.2010.05.005

Langley, E., Hooley, T., \& Bertuchi, D. (2014). A career postcode lottery? Local authority provision of youth and career support following the 2011 education act. Derby: International Centre for Guidance Studies, University of Derby.

Luken, T. (2009). Van kiezen naar leren. Naar een effectiever begrip van (studie)loopbaanbegeleiding [From choosing to learn. Towards a more effective understanding of (study) career]. Handboek Effectief Opleiden [Effective Training Manual], 11(7), 1-54. 
Mann, A., Massey, D., Glover, P., Kashefpadkel, E., \& Dawkins, J. (2013). Nothing in common: The career aspirations of young Britons mapped against projected labour marker demand (2010-2020). London: Education and Employers Taskforce, UKCES and b-Live.

Meijers, F. (1995). Arbeidsidentiteit; studie- en beroepskeuze in de post-industriële samenleving [Career identity; careers education and guidance in the post-industrial society]. Alphen a/d Rijn: Samsom H.D. Tjeenk Willink.

Meijers, F. (2001). The effects of the marketisation of career guidance services in the Netherlands. International Journal for the Advancement of Counselling, 23(2), 131-149. doi:10.1023/ A:1010671606971

Meijers, F., Kuijpers, M., \& Baker, J. (2006). Over leerloopbanen en loopbaanleren. Loopbaancompetenties in het (v)mbo [Learn about careers and career learning. Career Competencies in (V) MBO]. Driebergen: Het Platform BeroepsOnderwijs.

Meijers, F., Kuijpers, M., \& Gundy, C. (2013). The relationship between career competencies, career identity, motivation and quality of choice. International Journal for Educational and Vocational Guidance, 13(1), 47-66. doi:10.1007/s10775-012-9237-4

Milburn, A. (2013). Living standards, working poverty and social mobility. London: Resolution Foundation. Retrieved from: http://www.resolutionfoundation.org/media/media/downloads/Alan Milburn_Resolution_Foundation_final_speech_November_2013.pdf

Ministerie van Onderwijs en Wetenschappen [Ministry of Education and Science]. (1991). Beleidsbrief 'Studie- en beroepskeuzevoorlichting op scholen' [Policy letter 'Careers education in schools']. Zoetermeer: Author.

Mittendorff, K. (2010). Career conversations in senior secondary vocational education ( $\mathrm{PhD}$ thesis). Eindhoven University of Technology, Eindhoven.

Mittendorff, K., Brok, P.den, \& Beijaard, D. (2010). Career conversations in vocational schools. British Journal of Guidance \& Counselling, 38, 143-165. doi:10.1080/03069881003601007

National Connexions Partnership Ltd. (2005). Media Release 31/1/05. Retrieved from http://www. theguardian.com/society $/ 2005 / \mathrm{mar} / 02 /$ politics.childrensservices

National Careers Council (NCC). (2013). An aspirational nation: Creating a culture change in careers provision. London: Author.

Organisation for Economic Co-operation and Development (OECD). (2002). OECD review of career guidance policies: Netherlands country note. Paris: Author.

Organisation for Economic Co-operation and Development (OECD). (2004). Career guidance and public policy: Bridging the gap. Paris: Author.

Ofsted. (2013). The report of her majesty's chief inspector of education, children's services and skills. London: Office for Standards in Education, Children's Services and Skills.

Oomen, A. (2010). Ouders en de loopbaan van hun kind [Parents and career of their child]. Utrecht: APS.

Oomen, A., Van den Dungen, M., Pijls, T., \& Egelie, J. (2012). Career development in the Netherlands: State of play. 's-Hertogenbosch: Euroguidance Netherlands.

Opleiding en Beroep [Education and Occupation]. (2010). O\&O fondsen: subsidies en cursussen [R \& D funding: Grants and courses]. Retrieved May 20, 2013, from http://www.opleidingen beroep.nl/ts/ob/about.php?item=werkgevers\&subs $=3 \&$ subitem $=3$

Parliament (1993). Trade Union Reform and Employment Rights Act 1993 (Commencement No. 3 and Transitional Provisions) Order 1994. London.

Pere, H. M. (1986). Tussen arbeidsmarkt en individueel welzijn. Een historische analyse van de beroepskeuzevoorlichting in Nederland vanuit beroepensociologisch perspectief [Between labour market and individual well being; an historical analysis of careers guidance] ( $\mathrm{PhD}$ thesis). Educaboek, Culemborg.

Rees, T., \& Bartlett, W. (1999). Models of guidance services in the learning society: The case of the Netherlands. In F. Coffield (Ed.), Why's the beer always stronger up North? Studies of lifelong learning in Europe (pp. 21-30). Bristol: Policy Press.

Rees, T., Bartlett, W., \& Watts, A. G. (1999). The marketisation of guidance services in Germany, France and Britain. Journal of Education and Work, 12(1), 5-20. doi:10.1080/1363908990120101

Roberts, K. (2013). Career guidance in England today: Reform, accidental injury or attempted murder? British Journal for Guidance and Counselling, 41(3), 240-253. Retrieved from http:// www.tandfonline.com/doi/abs/10.1080/03069885.2013.773962\#.Uxj8gLnivDc.

Rosskam, E. (2006). Winners or losers? Liberalizing public services. Geneva: International Labor Office. 
Sabates, R., Harris, A. L., \& Staff, J. (2011). Ambition gone awry: The long term socioeconomic consequences of misaligned and uncertain ambitions in adolescence. Social Science Quarterly, 92(4), 959-977.

Scholt, E., Dekkers, L., \& Ketelaar, H. (2010). 4xL: Lang Leve Leren Laagopgeleiden. Van ideaal naar waar verhaal [4xL: Long live learning less educated. From ideal to true story]. 's-Hertogenbosch: PSW.

Skills Taskforce. (2014). Qualifications matter: Improving the curriculum and assessment for all Third report of the independent Skills Taskforce. London: Labour's Policy Review.

Smith, A. (1937). The wealth of nations. London: Modern Library E-book.

Social Mobility and Child Poverty Commission. (2013). State of the nation 2013: social mobility and child poverty in Great Britain. London: HMG Parliament.

Steeg, M. van der, Elk, R.van, \& Webbink, D. (2012). Does intensive coaching reduce school dropout? Evidence from a randomized experiment. The Hague: Centraal Planbureau/CPB.

Taborsky, O., \& De Grauw, M. (1974). Beroepskeuze; gedachten over het beroepskeuzeproces en over de methodiek van de beroepskeuzebegeleiding [Occupational choices; some thoughts about the process and methodology of careers guidance]. Haarlem: De Toorts.

UKCES. (2013). Employer ownership pilots. Wath-upon-Dearne: UK Commission for Employment \& Skills.

UKCES. (2014). UK Commission's employer skills survey 2013: UK results, Wath-upon-Dearne: UK Commission for Employment \& Skills.

Van den Berg, N., Meijers, F., \& Sprengers, M. (2006). More vocational education and supplementary training through equalization of costs? An analysis of a training and development fund in the Netherlands. Human Resource Development International, 9(1), 5-24. doi:10.1080/ 13678860500523072

Watts, A. G. (2001). Career guidance and social exclusion: A cautionary tale. British Journal of Guidance and Counselling, 29(2), 157-176.

Watts, A. G., \& Fretwell, D. (2004). Public policies for career development: Case studies and emerging issues for designing career information and guidance systems in developing and transition economies (World Bank Report No. 28598). Washington, DC: World Bank.

Watts, A. G., Hughes, D., \& Wood, M. (2005). A market in career: Evidence and issues, occasional Paper. Derby: International Centre for Guidance Studies.

Whitfield, D. (2006). New labour's attack on public services. Nottingham: Socialist Renewal, Fifth Series, 3,7 .

Winters, A., Meijers, F., Harlaar, M., Strik, A., Kuijpers, M., \& Baert, H. (2013). The narrative quality of career conversations in vocational education. Journal of Constructivist Psychology, 26(2), 115-126. doi:10.1080/10720537.2013.759026

Winters, A., Meijers, F., Kuijpers, M., \& Baert, H. (2012b). Can training stimulate career learning conversations? Analysis of vocational training conversations in Dutch secondary vocational education. Journal of Vocational Education and Training, 64, 1-18. doi:10.1080/10720537.2013.759026

Winters, A., Meijers, F., Lengelle, R., \& Baert, H. (2012a). The self in career learning: An evolving dialogue. In H. Hermans \& T. Gieser (Ed.), Handbook of dialogical self theory (pp. 454-469). Cambridge, MA: Cambridge University Press.

Wolf, H. R. (1994). Fifteen years of parliamentary debates about careers education and guidance. In Center for parliamentary history, political drafting 14 (pp. 147-161). Nijmegen: Catholic University of Nijmegen.

Yates, S., Harris, A., Sabates, R., \& Staff, J. (2011). Early occupational aspirations and fractured transitions: A study of entry into 'NEET' status in the UK. Journal of Social Policy, 40, 513-534. doi:10.1017/S0047279410000656

Zoetmulder, M. (2010). Monitoring Inbedding Leerwerkloketten [Monitoring embedding learning and working desks]. Amsterdam: UWV WERKBedrijf. 